DOI: https://doi.org/10.31392/NZ-npu-142.2019.20

УДК 378.014.6:005.6](477)

ORCID: 0000-0002-9217-0204

Одайський C. I.

\title{
СУЧАСНІ ВИМІРИ ТА ПРІОРИТЕТИ РОЗВИТКУ ВИЩОЇ ОСВІТИ: ПОРІВНЯЛЬНИЙ АСПЕКТ
}

Статтю присвячено розкриттю сучасних ідей, вимог, пріоритетів та позицій науковиів у порівняльному аспекті щуодо перспектив розвитку вищої освіти України та ї̈ інтегращії в європейський освітній простір. Акцентується увага на питанні вивчення й упровадження в діяльність вітчизняних $3 В О$ європейського досвіду вищої освіти та досягнень світових університетів, враховуючи автономію, академічну мобільність $i$ академічні свободи. Окреслюються шляхи забезпечення якості вищої освіти та якості освітньої діяльності $3 В О$ в умовах суспільних змін.

Зроблено порівняльний аналіз ідей, вимог, пріоритетів, наукових позицій щудо перспектив та иляхів розвитку вищої освіти України в період реформаційних освітніх перетворень; акиентування тих аспектів, які пов'язані з вивченням і впровадженням європейського досвіду вищої освіти на засадах иілей $i$ завдань Болонського процесу та досягнень університетів світового рівня; розкриття питань забезпечення системи якості вищої освіти та якості освітньої діяльності ЗВО, впровадження автономії, академічної мобільності та академічних свобод; висвітлення змін, щзо відбуваються в міжнародному $і$ національному освітньому просторі на сучасному етапі його розвитку та знаходять своє відображення в нормативноправових документах.

Закиентувано увагу на розв'язанні одного з важливіших завдань розвитку вищої освіти на сучасному етапі реформування й модернізації освітньої галузі, а саме: створення иілісної системи забезпечення якості вищої освіти України та успішну реалізаџію ї̈ складових в контексті сучасних освітніх змін та впливів, базуючись на стратегічних иілях $i$ завданнях вищої освіти. Науковій і освітянській спільноті важливо виконати далекоглядну суспільну місію - зберегти кращі надбання $і$ здобутки украӥнської вищої школи та попередити втрату національної ідеї освіти, зміст якої полягає в збереженні і примноженні національних освітніх традииій.

Ключові слова: вища освіта, заклад вищої освіти (ЗВО), автономія, академічна мобільність, академічна свобода, якість вищої освіти, якість освітньої діяльності, Європейський простір вищої освіти $(Є П В О)$.

В масштабі глобальних соціально-економічних трансформацій на початку третього тисячоліття переосмислюється роль та цілі вищої освіти, головним вектором реалізації яких $€$ якісні перетворення в системі університетської освіти, створення оптимальних умов, отримання студентами якісної освіти, вироблення знання, здійснення наукових досліджень, намагання університетів досягти академічної досконалості - стати університетами світового класу. Це знайшло відображення у Програмі ООН “Цілі 2030: Освіта для сталого розвитку" (E ducation for Sustainable Development).

Тобто, реагуючи на виклики часу, освіта принципово працює на майбутнє, визначаючи особистісні якості кожної людини, їі знання, вміння, навички, світоглядні та поведінкові пріоритети, а отже, у підсумку - економічний, 
моральний і духовий потенціал суспільства, цивілізації в цілому [4, с. 18].

Відповідно до вказаних особливостей на загальнодержавному рівні консолідується роль вищої освіти як основного елементу формування інтелектуального потенціалу нації, перетворення України в передову європейську державу та її успішну інтеграцію у світове співтовариство. У зв'язку з цим актуалізуються такі важливі аспекти вищої освіти, як:

- структурна модернізація галузі, її багатовекторність;

- розвиток транснаціональної освіти;

- регіональна і міжрегіональна кооперація;

- інформаційні й комунікаційні технології освіти;

- віртуальні університети;

- корпоративні університети;

- рівний доступ до вищої освіти.

Слід зазначити, що на сьогодні дослідниками створено низьку наукових праць, присвячених актуальним питанням зростання ролі вищої освіти як провідної суспільної сили щодо підготовки за сучасними вимогами професійних кадрів та як дієвого механізму забезпечення економічного й соціальнокультурного рівня життєдіяльності суспільства. Серед них: Л. Губерський, А. Гуржій, М. Дебич, О. Дубасенюк, М. Згуровський, І. Зязюн, К. Корсак, В. Кремень, В. Луговий, С. Максименко, С. Ніколаєнко, О. Соснін.

Всебічний аналіз процесів, що відбуваються у сорері вищої освіти, 3 позицій фрілософії, соціології та правознавства представлений у працях В. Андрущенка, Б. Гершунського, О. Гончарової, М. Євтуха, С. Клепка, Ю. Корсака, О. Линовицької, П. Сауха, І. Силадія, Н. Хамітова.

Питання реформування системи вищої освіти в Україні та модернізації діяльності 3ВО під впливом новітніх технологій і освітніх інновацій, передових ідей та досвіду досліджують С. Бебко, Я. Болюбаш, С.Гала, В.Галах, Д. Дзвінчук, Л. Івлєва, Г. Клімова, М. Кляп, О. Козієвська, В. Кремень, О. Куклін, В. Огнев'юк, А. Похресник, Є. Сідоріна, О. Старицька, Ю. Сухарніков.

Окремі аспекти автономії, академічної мобільності та академічної свободи вивчають В. Андрущенко, О. Власюк, Т. Дараган, О. Линовицька, В. Мокляк, Д. Свириденко, Н. Тимошенко. Обґрунтуванню питань якості вищої освіти та якості освітньої діяльності закладів освіти в умовах реалізації Болонського процесу присвячено праці І. Беха, В. Головенкіна, Г. Клімової, О. Корнілової, Г. Красильникової, О. Левченка, С. Ніколаєнка, П. Сікорського, С. Сисоєвої.

Наукові підходи щодо визначення особливостей управління системою вищої освіти розглядають Ю. Алферов, А.Галаган, Є. Сергієнко, О. Скідін, М. Яковенко, В. Янкевич.

Наведене підтверджує актуальність і необхідність обґрунтування сучасних вимог, які стосуються вдосконалення системи вищої освіти України, підвищення ефективності і рівня діяльності вітчизняних ЗВО щодо надання освітніх послуг з підготовки фрахівців-професіоналів, розроблення й упровадження концепцій, програм, рекомендацій у контексті забезпечення умов, засобів, можливостей і успіху модернізації освітнього процесу в системі вищої освіти на державному та міжнародному рівнях.

Метою статmi є порівняльний аналіз ідей, вимог, пріоритетів, наукових позицій щодо перспектив та шляхів розвитку вищої освіти України в період 
рефрормаційних освітніх перетворень; акцентування тих аспектів, які пов'язані $з$ вивченням і впровадженням європейського досвіду вищої освіти на засадах цілей і завдань Болонського процесу та досягнень університетів світового рівня; розкриття питань забезпечення системи якості вищої освіти та якості освітньої діяльності ЗВО, впровадження автономії, академічної мобільності та академічних свобод; висвітлення змін, що відбуваються в міжнародному і національному освітньому просторі на сучасному етапі його розвитку та знаходять своє відображення в нормативно-правових документах.

У розкритті окресленої проблематики ми виходимо з того, що зміна умов життя у світі, їхня багатоманітність, складність і нестабільність вимагають від ЗВО постійних зусиль, спрямованих на адаптацію до цих змін. У цьому значну роль відіграє пошук найбільш доцільної форми пристосування закладу освіти до оточуючого соціокультурного середовища, що відповідно трансформується під впливом дії зовнішніх та внутрішніх фракторів.

Водночас, з огляду на особливості реформаційних процесів в освіті, для того, щоб забезпечити сьогодні ефективне функціонування ЗВО, необхідно перш за все запровадити основи університетської автономії як однієї з базових засад децентралізації й демократизації в академічній, організаційній, фрінансовій та управлінській сфрерах [6, с. 42-43].

При цьому автономія ЗВО має здійснюватися 3 урахуванням європейського та світового досвіду, що ґрунтується на принципах, закладених в Magna Charta Universitatum (1988р.), Ерфуртській декларації (1996р.), Лісабонській конвенції (1997р.), Болонській декларації (1999р.), Хартії університетів України (2009р.).

Саме ці важливі освітні документи визначають сучасну роль і місце 3 ВО в освітньо-науковому просторі, його місію, автономію, академічну мобільність і академічні свободи учасників освітнього процесу та суспільну відповідальність, а також забезпечують реалізацію національної політики у сфері вищої освіти за європейськими стандартами та нормами [14].

Конкретизуємо дане питання 3 позиції нормативно-правого регламентування та регулювання вищезазначених процесів.

У Законі України "Про вищу освіту" (2014р.) [16] автономія визначається як самостійність, незалежність і відповідальність закладу вищої освіти у прийнятті рішень стосовно розвитку академічних свобод, організації освітнього процесу, наукових досліджень, внутрішнього управління, економічної та іншої діяльності, самостійного добору і розстановки кадрів у межах, встановлених цим Законом (ст. 1, п. 1.1).

Підкреслимо, що впровадження основ університетської автономії відповідає потребі подальшої демократизації не тільки академічного життя, а й суспільних процесів у цілому. Тому права ЗВО, встановлені цим Законом, не можуть бути обмежені іншими законами чи нормативно-правовими актами (ст. 2, п. 3).

Важливими в цьому аспекті є: академічна мобільність, яка надає можливість учасникам освітнього процесу навчатися, викладати, стажуватися чи проводити наукову діяльність в іншому закладі вищої освіти (науковій установі) на території України чи поза їі межами (ст. 1, п. 1.2); академічна свобода, яка визначає самостійність і незалежність учасників освітнього 
процесу під час провадження педагогічної, науково-педагогічної, наукової та/або інноваційної діяльності, що здійснюється на принципах свободи слова і творчості, поширення знань та інформації, проведення наукових досліджень і використання їх результатів та реалізується 3 урахуванням обмежень, встановлених законом (ст. 1, п. 1.3).

Відповідно суттєво зростає відповідальність ЗВО за самоорганізацію, саморегулювання, прозорість та публічність освітнього процесу (ст. 3, п. 3.5). Поряд з цим ЗВО одержали право самостійно розробляти і впроваджувати освітні та наукові програми, нові спеціалізації, приймати рішення стосовно розвитку академічних свобод, організації освітнього процесу, проведення фундаментальних та прикладних наукових досліджень, внутрішнього управління, економічної та іншої діяльності, самостійного добору й розстановки кадрів у межах, передбачених законом (ст. 29, п. 3).

Законодавчі ініціативи передбачають також право 3ВО здійснювати підготовку фахівців з вищою освітою за власними експериментальними освітніми програмами та навчальними планами (ст. 29, п. 4); визначати способи досягнення раніше встановлених пріоритетів як частини національної політики щодо підготовки фахівців 3 вищою освітою для пріоритетних галузей економічної діяльності, визначати власну академічну структуру і обсяг освітньої та професійної підготовки фахівців з вищою освітою (ст. 3).

Водночас імплементація Закону розширила можливості інноваційної діяльності 3ВО, а саме: право формувати на своїй базі інноваційні структури різних типів (наукові та технологічні парки, бізнес-інкубатори, малі підприємства тощо) на засадах поєднання інтересів високотехнологічних компаній, науки, освіти, бізнесу та держави з метою виконання і впровадження інноваційних проектів (ст. 29, п. 7).

Безумовно, зазначені вище регламенти на практиці означають не тільки певне обмеження керівної функції держави, а й підвищення відповідальності самого ЗВО за якість освітніх послуг, які він надає, вибір пріоритетів, змісту і напрямів власної діяльності, а, відтак, право здійснювати на цьому шляху відповідні перетворення і досягати поставлених цілей.

Отже, об'єктивним і несуперечливим $€$ розуміння шляхів вирішення цих проблем: по-перше, формування стратегії цілеспрямованого розвитку сучасного ЗВО як головної умови оновлення вищої освіти; по-друге, розширення автономії ЗВО як невід'ємної складової реформування вищої світи України та її входження до ЄПВО.

Виходячи з цього, варто закцентувати увагу на розв'язанні одного 3 важливіших завдань розвитку вищої освіти на сучасному етапі реформування й модернізації освітньої галузі, а саме: створення цілісної системи забезпечення якості вищої освіти України та успішну реалізацію ії складових в контексті сучасних освітніх змін та впливів, базуючись на стратегічних цілях і завданнях вищої освіти [5; 12. с. 8-10].

У важливому міжнародному документі ЮНЕСКО “Всесвітня декларація про вищу освіту для XXI століття: підходи і практичні заходи" (1998р.) [3] якість у галузі вищої освіти інтерпретується як "багатовимірна концепція, яка повинна охоплювати всі їі функції і види діяльності: навчальні і академічні програми; наукові розробки і стипендії; комплектацію кадрами; учнів; будівельні споруди; 
матеріально-технічну базу; устаткування; роботу на благо суспільства і академічне середовище" (ст. 11).

Водночас, у Законі України “Про вищу освіту" [16] якість вищої освіти визначається як відповідність результатів навчання вимогам, встановленим законодавством, відповідним стандартом вищої освіти та/або договором про надання освітніх послуг (ст. 1, п. 23); якість освітньої діяльності - як рівень організації освітнього процесу у закладі вищої освіти, що відповідає стандартам вищої освіти, забезпечує здобуття особами якісної вищої освіти та сприяє створенню нових знань (ст. 1, п. 24).

У науковій літературі поняття "якість вищої освіти" трактується більш широко, а саме як: 1) соціальний інститут; 2) педагогічний процес; 3) суспільний процес; 4) процес суб'єкт-суб'єктної взаємодії; 5) загальноцивілізаційний феномен; 6) соціокультурна система та ін. [11, с. 36].

Система забезпечення якості вищої освіти в Україні включає три складові (ст. 16, п.1) [16]:

1) системи забезпечення закладами вищої освіти якості освітньої діяльності та якості вищої освіти (система внутрішнього забезпечення якості);

2) системи зовнішнього забезпечення якості освітньої діяльності закладів вищої освіти та якості вищої освіти;

3) системи забезпечення якості діяльності Національного агентства із забезпечення якості вищої освіти (НАЗЯВО) і незалежних установ оцінювання та забезпечення якості вищої освіти.

Слід уточнити, що реалізація державної політики у сфрері якості вищої освіти забезпечується спільною діяльністю уряду, МОН України, ЗВО, НАЗЯВО і незалежних установ, які оцінюють якість підготовки фрахівців у ЗВО, та включає внутрішню і зовнішню системи [15, с. 22].

I. Внутрішня система забезпечення якості:

- кадровий потенціал 3ВО, навчально-методичне, матеріально-технічне та інформаційне забезпечення освітнього процесу;

- моніторинг та періодичний перегляд освітніх програм;

- наявність інформаційних систем для ефективного управління освітнім процесом;

- аналіз якості освітньої діяльності 3ВО;

- періодичні перевірки функціонування системи забезпечення якості діяльності 3ВО;

- публічність інформації про освітні програми, ступені вищої освіти та кваліфікації.

II. Зовнішня система забезпечення якості:

- акредитація освітніх програм, за якими здійснюється підготовка здобувачів вищої освіти;

- щорічне оцінювання здобувачів вищої освіти, науково-педагогічних і педагогічних працівників за критеріями оцінювання згідно зі стандартами та рекомендаціями ЄПВО, регулярне оприлюднення його результатів;

- підвищення кваліфікації педагогічних, наукових і науково-педагогічних працівників;

- оцінювання діяльності 3ВО щодо забезпечення якості вищої освіти незалежним акредитованим органом; 
- запобігання та виявлення академічного плагіату.

Разом з тим зауважимо, що на сьогодні питання створення завершеної системи вищої освіти, важливими складовими якої $€ 3$ ВО всіх фрорм власності, рівні та ступені (кваліфікації) вищої освіти, галузі знань і спеціальності, освітні і наукові програми, стандарти освітньої діяльності та стандарти вищої освіти, органи, що здійснюють управління у сфері вищої освіти, учасники освітнього процесу (ст. 11) [16], залишається на стадії вирішення й послідовної реалізації в освітній практиці в повному обсязі.

У цьому сенсі слід подолати деякі розбіжності, що існують у підходах українського освітнього законодавства та міжнародних правових документів 3 питань освіти і професійної підготовки фахівців з вищою освітою для їхнього вступу на національний та міжнародний ринки праці.

Нагадаємо, що вхідні пріоритети для європейської вищої освіти до 2020 року були сформульовані на конференції Міністрів, відповідальних за вищу освіту, з 46 країн-учасниць Болонського процесу в Льовен / Лувен-ла-Нев (Бельгія, 2009 р.) [2]. Вони включають:

- підготовка студентів для їх майбутньої кар'єри і створення умов для їх особистого розвитку;

- європейські цінності інституційної автономії, академічні свободи та соціальна справедливість;

- висока цінність різноманітності систем освіти;

- безперервне навчання, засноване на принципі громадської відповідальності;

- розвиток національних кваліфікаційних рамок;

- придатність до працевлаштування;

- особистісно-орієнтоване навчання;

- мобільність студентів, дослідників і співробітників в області транснаціональної освіти.

Цілі і повноваження ЄС у здійсненні політики професійної підготовки кадрів визначені в Угоді про Європейський союз [7]. Для їх виконання дії співтовариства спрямовані на такі сегменти співпраці:

- адаптація до змін у промисловості, зокрема за допомогою професійної підготовки і перепідготовки;

- поліпшення первісної і безперервної професійної підготовки з метою сприяння професійній інтеграції й реінтеграції у ринок праці;

- стимулювання співпраці у сфері підготовки кадрів між освітніми закладами або установами з професійної підготовки і фірмами.

При цьому особливістю європейського підходу є те, що освіта (education) i профресійна підготовка (vocational training) у назві розділу VIII Угоди (title VIII. Social Policy, Education, Vocational Training and Touth) наводяться через кому як напрями діяльності ЄС. Як бачимо, вища освіта поєднує поняття навчання та професійної підготовки: перше надає фрізичній особі власне освіченість, друге професійну кваліфрікацію з певної спеціальності в обраній галузі діяльності як надійне джерело матеріального добробуту [20, с. 38].

Доцільність визначення дуальності вищої, тобто професійної, освіти в ЄПВО підтверджується світовою практикою поділу ЗВО на дві групи з різними концепціями вищої освіти. 
Перша дотримується класичного уявлення про ЗВО як джерело глобальної, в основному гуманітарної, освіти; друга враховує реалії індустріального суспільства та його спрямованість на конкретні технологічні напрями. Залежно від національних освітніх платформ на базі цих концепцій у світі утворилися чотири основні типи ЗВО (університетів) - англійський, німецький, французький та американський. При цьому перші два мають розвинуті традиції фундаментальної освіти, що спирається як на природничі, так і на спеціальні науки. Американські 3ВО дотримуються прагматичної орієнтації на підготовку фахівців для конкретних галузей економіки [8, с. 10].

У даному контексті погоджуємося 3 думкою Ю. Сухарнікова та Ю. Зінківського, що така позиція європейської освітянської спільноти $\epsilon$ визначальним моментом у міжнародному правовому регулюванні питань освіти і професійної підготовки населення країн ЄС. Адже обраний концептуальний підхід, за яким освіта розглядається як загальне, а професійна підготовка як їі складова (спеціальне), дозволяє урядам і державним органам управління формулювати чіткі збалансовані цілі і завдання освітньої політики, визначати принципи, форми, зміст, засоби, напрями і перспективи розвитку освіти та профресійної підготовки, придатних для забезпечення повноцінного життя і продуктивної діяльності кожної людини в сучасному цивілізованому суспільстві.

Разом з тим слід підкреслити, що в Законі України “Про вищу освіту” [16] вища освіта розглядається в більш широкому нормативно-правовому форматі як сукупність систематизованих знань, умінь і практичних навичок, способів мислення, профресійних, світоглядних і громадянських якостей, моральноетичних цінностей, інших компетентностей, здобутих у закладі вищої освіти (науковій установі) у відповідній галузі знань за певною кваліфікацією на рівнях вищої освіти, що за складністю $€$ вищими, ніж рівень повної загальної середньої освіти (ст. 1, п. 5).

Отже, на принциповій основі можна стверджувати, що вища освіта сьогодні складає фундамент розбудови Української держави, оскільки саме в ній формується особистість як компетентний фахівець, носій інтелектуальних здібностей і знань, соціокультурного досвіду, нових духовних і культурних цінностей та життєвих настанов. Водночас, професійно підготовлений у ЗВО, фахівець стає свідомою в своєму виборі особистістю, активним учасником розбудови економічного, суспільного й культурного життя, перетворення України в високорозвинуту країну як рівноправного партнера міжнародної спільноти націй і народів.

Вирішення зазначених проблем знаходиться в площині фрормування i реалізації державної політики у сорері вищої освіти, що забезпечується шляхом:

1) гармонійної взаємодії національних систем освіти, науки, мистецтва, бізнесу та держави з метою забезпечення стійкого соціально-економічного розвитку держави;

2) збереження і розвитку системи вищої освіти та підвищення якості вищої освіти;

3) розширення можливостей для здобуття вищої освіти та освіти протягом життя;

4) створення та забезпечення рівних умов доступу до вищої освіти;

5) розвитку автономії 3ВО та академічної свободи учасників освітнього 
процесу;

6) визначення збалансованої структури та обсягу підготовки фахівців 3 вищою освітою з урахуванням потреб особи, інтересів держави, територіальних громад і роботодавців;

7) забезпечення розвитку наукової, науково-технічної, мистецької та інноваційної діяльності 3ВО та їх інтеграції з виробництвом;

8) надання особам, які навчаються у ЗВО, пільг та соціальних гарантій у порядку, встановленому законодавством;

9) належної державної підтримки підготовки фахівців з числа осіб 3 особливими освітніми потребами на основі створення для них вільного доступу до освітнього процесу та забезпечення спеціального навчальнореабілітаційного супроводу;

10) створення умов для реалізації випускниками 3ВО права на працю, забезпечення гарантії рівних можливостей щодо вибору місця роботи, виду трудової діяльності з урахуванням здобутої вищої освіти та відповідно до суспільних потреб;

11) запровадження механізмів стимулювання підприємств, установ, організацій усіх фрорм власності до надання першого робочого місця випускникам 3ВО (ст. 3, п. 2) [16].

У цьому зв'язку, враховуючи той фракт, що в умовах розвитку глобальної економіки знань та становлення знаннєвого суспільства вища освіта перетворилася на важливіший чинник економічного піднесення країни та зростання її конкурентоспроможності на світовому ринку, варто наголосити на вимогах, реалізація яких забезпечує підвищення якості вищої освіти: надання якісно нового рівня знань, підготовка кадрів вищої кваліфікації, охоплення населення системою безперервної освіти, формування та розвиток сучасної інфраструктури закладів освіти [9, с. 50].

Поряд з цим важливою $є$ позиція Г. Клімової, яка запропонувала свою програму дій щодо переходу вітчизняних 3ВО в режим інноваційного розвитку як стратегічної мети та сформулювала такі цілі: фрормування єдиного культурно-освітнього й наукового простору; створення ефективної компетентнісно-контекстної педагогічної моделі підготовки бакалавра і магістра; залучення всього колективу до інноваційного освітнього процесу; системна модернізація освітньої діяльності; встановлення ділових зв'язків 3 органами державної влади, установами освіти і науки, роботодавцями, громадськими організаціями; здійснення програм координації діяльності 3 інноваційного розвитку; розширення програм міжнародної співпраці [10, с. 94].

До вказаного слід додати слушну думку О. Кукліна, який вважає, що українські ЗВО мають бути серед найбільш відомих європейських та світових університетів. Для цього необхідне опанування інноваційного шляху, що забезпечить розвиток вітчизняної системи вищої освіти, підвищить її якість та конкурентоспроможність. Відповідно державна освітня політика має стимулювати розроблення інноваційної стратегії розвитку 3ВО, адже в умовах формування економіки знань необхідно усвідомлювати кардинальну потребу освітніх перетворень та новітніх досягнень у напрямі інноваційного розвитку країни [13].

Серед інших проблем, які вимагають нагального вирішення на різних 
рівнях управління системою вищої освіти, слід виділити:

- складність оцінювання можливого впливу ринкової економіки на сфреру вищої освіти, яка на сьогоднішній день має досить малий досвід функціонування в умовах ринкових відносин та зростаючої конкуренції на ринку освітніх послуг;

- застаріле, консервативне уявлення в свідомості людей про освіту взагалі та вищу зокрема, як про благо, а не як про товар, хоча освіта давно несе в собі риси товару;

- значне скорочення бюджетного фрінансування вищої освіти, що в умовах системної економічної кризи та різкого скорочення доходів сімей або втрати роботи студентів може привести до скорочення доходів 3ВО, особливо провінційних 3ВО або фрілій столичних 3ВО, що, у свою чергу, поглибить кризу вітчизняної освіти, в тому числі вищої та професійної;

- поширення нової форми прояву комерціалізації вищої освіти, яка передбачає організаційну перебудову ЗВО у бізнес-структури, отримання закладом освіти прибутку від різних видів освітньої діяльності, надання різноманітних додаткових послуг, а не за рахунок розробки й реалізації науково-дослідницьких та інженерно-консалтингових проектів, а також активної співпраці з зарубіжними партнерами у сфері освітніх програм і створення бази міжнародних навчальних програм для ЗВО і студентів [18, с. 60-61].

Щодо питання зближення у сфері вищої освіти, ми підтримуємо позицію Ю. Сухарнікова про те, що на сучасному етапі реформування освітньої галузі акцент слід зробити на положенні Болонської декларації, а також вищезазначених міжнародних документів у галузі вищої освіти про необхідність забезпечення успішного працевлаштування випускників ЗВО за рахунок того, що одержані академічні кваліфікації та компетенції відповідного рівня мають бути орієнтовані на ринок праці [20, с. 40].

Разом з тим, учені переконані, що державна політика у сфрері освіти має орієнтуватися на формування людського потенціалу суспільства, а відтак, сприяти реалізації прав громадян на повну, продуктивну і вільно вибрану зайнятість. 3 цього приводу в Законі України "Про зайнятість населення" (2012р.) [17] зазначається, що державна політика зайнятості населення базується на принципах: пріоритетності забезпечення повної, продуктивної та вільно обраної зайнятості у процесі реалізації активної соціально-економічної політики держави; відповідальності держави за фрормування та реалізацію політики у сорері зайнятості населення (ст. 15).

Метою державної політики у цій сфрері $€$ сприяння підвищенню професійного рівня працездатного населення відповідно до суспільних потреб, тому заходи щодо сприяння зайнятості населення мають бути спрямовані на забезпечення відповідності рівня професійної кваліфікації працездатних осіб потребам ринку праці; підвищення конкурентоспроможності осіб на ринку праці (ст. 24).

До заходів зі сприяння зайнятості населення, зокрема в освітній сфрері, належать: професійна орієнтація та професійне навчання, сприяння забезпеченню молоді першим робочим місцем та запровадження стимулів для стажування на підприємствах, в установах та організаціях незалежно від форми власності, виду діяльності та господарювання, фізичних осіб, які застосовують 
найману працю молоді, яка навчається.

Це означає, що в умовах швидкого розвитку потреб ринку праці прийнятий нормативно-правовий акт має націлити ЗВО на задоволення перш за все економічних потреб держави та інтересів громадян в отриманні обраної професійної кваліфікації. Крім того, ЗВО слід зосереджувати свою діяльність на кінцевому результаті - знаннях, уміннях і компетенціях випускників, які мають практичну спрямованість і будуть затребувані на ринку праці.

До інших важливих заходів слід віднести: підвищення конкурентного статусу закладу освіти на національному й регіональному рівні; поглиблення участі у грантових програмах і проектах та програмах міжнародної академічної мобільності; підтримування широких міжнародних зв'язків з провідними європейськими університетами в рамках перебудови (reforming) й осучаснення (modernising) системи вищої освіти на основі сертифікування Національної рамки кваліфікацій України, одержання нормативного права брати участь у легітимації й нострифікації документів про вищу освіту в ЄПВО [20, с. 37].

Вважаємо, що в зазначеному аспекті в Україні доцільно, крім європейського, використати також елементи китайського досвіду організації системи вищої освіти та регулювання ії̈ функціонування на державному й регіональному рівнях з урахуванням глобальних тенденцій розвитку світової освітньої системи та потреб національного ринку праці у кваліфікованих фрахівцях.

Зокрема, групою вітчизняних учених (С. Бебко, С. Гала, І. Каленюк, А. Марчук) виокремлено ключові чинники підвищення ефективності сфрери вищої освіти у Китаї, серед яких:

- висока кваліфікація науково-педагогічних працівників (що обумовлюється поступовим підвищенням кваліфікаційних вимог до академічного персоналу);

- поширена практика запрошення до викладання іноземних профресорів;

- розширення державного замовлення на підготовку фахівців з вищою освітою, передусім у технічній та технологічній сферах, що створює сприятливе підґрунтя для збільшення обсягів фрінансування, в тому числі для фрормування належної матеріально-технічної бази:

- наявність програм грантової підтримки наукових досліджень та молодих учених; міжнародна взаємодія науково-педагогічних працівників;

- підвищення рівня автономії 3ВО (академічної, управлінської, фінансової), що дає змогу повноцінно врахувати потенціал закладу та реалізувати поставлені перед ним завдання;

- підтримка результативної наукової та інноваційної діяльності, яка дозволяє отримувати наукові та інноваційні продукти і реалізовувати їх на відкритому ринку;

- підтримка програм із залучення на навчання іноземних студентів (включаючи безкоштовне вивчення китайської мови, стипендії для кращих студентів, підтримку програм студентських обмінів);

- організація моніторингу контролю за якістю діяльності ЗВО та якістю освіти в умовах масовості вищої освіти;

- удосконалення механізму акредитації 3ВО, представлення наукових результатів у міжнародних науково-метричних базах даних, підтримка 
інноваційної діяльності студентів і викладачів;

- укладання міжнародних і міжурядових угод про співробітництво у сфері вищої освіти та наукових досліджень;

- широка модернізація освітніх закладів, у т. ч. на ґрунті застосування механізмів державно-приватного партнерства (бізнес-структури, державні установи, роботодавці);

- якісне фінансове забезпечення ЗВО за рахунок коштів державного бюджету, коштів споживачів освітніх послуг, участі у проектах та міжнародних наукових програмах, залучення іноземних фінансових ресурсів [1, с. 65-66].

Відтак, стає очевидною доцільність використання у вітчизняний практиці вищої освіти кращих елементів китайського досвіду та інших передових країн щодо модернізації ЗВО на основі реалізації державної політики в галузі вищої освіти, досягнень науково-технологічного прогресу, організації державного інвестування в підготовку фахівців з вищою освітою, підтримки й регулювання розвитку національного ринку освітніх послуг та визначення стратегічної мети, цілей і завдань діяльності закладів освіти в умовах євроінтеграції.

Висновки. Вивчення літературних джерел, матеріалів періодики, нормативно-правових документів у галузі вищої освіти та аналіз досліджених наукових позицій доводить наступне.

1. Система вищої освіти України, враховуючи наявні проблеми та перспективи розвитку, достатньою мірою відображає новітні тенденції світової та європейської освітньої практики і містить такі концептуальні засади, як:

- здійснення національної освітньої політики відповідно до європейських вимог та стратегії розвитку вищої освіти України;

- структурна модернізація вищої освіти;

- інтеграція вищої освіти і науки;

- розроблення й упровадження державних стандартів вищої освіти;

- розвиток Національної рамки кваліфікацій;

- надання автономії ЗВО, академічної мобільності і академічної свободи учасникам освітньої діяльності;

- вдосконалення системи підготовки фахівців-профресіоналів у ЗВО з урахуванням вимог національного та міжнародного ринків праці;

- зростання суспільної відповідальності ЗВО за організацію освітнього процесу і результати своєї діяльності;

- розроблення механізму об'єктивного оцінювання якості освіти і якості професійної підготовки майбутніх фахівців у ЗВО;

- децентралізація управлінської діяльності 3ВО;

- об'єктивна неминучість інтеграції вищої освіти України в міжнародний освітній простір, а українського суспільства - в європейську спільноту держав.

2. Для забезпечення підготовки висококваліфікованих фрахівців у системі вищої освіти слід підвищити якість і ефрективність діяльності ЗВО за такими напрямами:

- кардинальна модернізація наукової та освітньої матеріально-технічної бази;

- удосконалення механізмів державно-приватного партнерства, бюджетного фінансування діяльності, формування державного замовлення на підготовку фрахівців з вищою освітою, державного контролю за результатами 
освітньої діяльності та якості вищої освіти;

- стимулювання наукової та інноваційної діяльності, яка може виступати й елементом освітнього процесу, і бути джерелом додаткових доходів;

- розробка та впровадження сучасних інноваційних освітніх технологій, зокрема технологій дистанційної освіти;

- підтримка взаємодії з науковими установами та роботодавцями;

- активізація міжнародної діяльності та міжнародних відносин між 3ВО.

3. У пошуку шляхів розвитку вищої освіти науковій і освітянській спільноті важливо виконати далекоглядну суспільну місію - зберегти кращі надбання і здобутки української вищої школи та попередити втрату національної ідеї освіти, зміст якої полягає в збереженні і примноженні національних освітніх традицій, що в умовах сьогодення $є$ ідентичним до вибору історичного шляху та перспектив розвитку незалежної Української держави в XXI столітті.

\section{Використана література :}

1. Бебко С. Перспективи розвитку ринку освітніх послуг України 3 урахуванням китайського досвіду. Вища школа. 2018. № 3. С. 62-70.

2. Болонський процес 2020 - Простір європейської вищої освіти у новому десятиріччі. Комюніке Конференції Європейських міністрів, відповідальних за вищу освіту. Льовен / Лувен-ла-Нев, 2829 квітня 2009. URL: http://pedagogy.Inu.edu.ua/departments/ pedagogika/bolon/10.pdf.

3. Всесвітня декларація про вищу освіту для XXI століття: підходи і практичні заходи, 1998. URL: http://euroeducation.org.ua/inshi-programni-dokumenty/lvsesvitnya-deklaraciya-pro-vyshchu-osvitudlya-hhi-stolittya-pidhody-i.

4. Гершунский Б. С. Философия образования для XXI века (в поисках практико-ориентированныХ образовательных концепций). Москва : Совершенство, 1998. 432 с.

5. Головенкін В. Університетська система забезпечення якості. Вища школа. 2014. № 11-12. С. 15-23.

6. Дараган Т., Тимошенко Н., Власюк О. Автономія вищих навчальних закладів: нормативноправові акти, встановлені Законом України “Про вищу освіту". Вища школа. 2017. № 7. С. 40-45.

7. Договор о Европейском Союзе. Мастрихт, 7 февраля 1992 г. URL: https://zakon.rada.gov.ua/ laws/show/994_029 http://www.hri.org/does/Rome57/ Premble.html.

8. Зіньковський Ю. Імператив сучасної парадигми вищої освіти. Вища школа. 2013. № 9. С. 7-19.

9. Івлєва Л., Сідоріна $Є$., Карбовська С. Перспективи інноваційного розвитку освіти. Вища школа. 2013. № 10. C. 49-58.

10. Клімова Г. П. Інноваційний розвиток вищої освіти України: методологічний аспект аналізу. Актуальні питання інноваційного розвитку: Всеукраїнська науково-практична конференція. 2012. № 3. С. 90-105.

11. Клімова Г.П. Інтерпретація поняття "якість вищої освіти": соціолого-філософська рефлексія Юридична академія Украйни імені Ярослава Мудрого : вісник Національного університету. Серія : Філософія. 2016. №3. С. 34-44.

12. Кремень В.Г. Проблеми якості української освіти в контексті сучасних цивілізаційних змін. Украӥнський педагогічний журнал. 2015. № 1. С. 8-15.

13. Куклін О. В. Концептуальні засади інноваційного розвитку вищих навчальних закладів. URL : http://www.economy.nayka.com.ua/?op $=1 \& z=1186$.

14. Линовицька О. Академічні свободи та університетська автономія. Вища освіта України. 2011. № 3. C. 27-31.

15. Погребняк В., Дашковська О., Солоденко А. До проблем створення системи забезпечення якості вищої освіти у вітчизняній вищій школі. Вища школа. 2018. № 7-8. С. 21-27

16. Про вищу освіту: Закон України від 01.07.2014 № 1556-VII. URL : https://zakon.rada.gov.ua/ laws/show/1556-18.

17. Про зайнятість населення: Закон України від 05.07.2012 № 5067-VII. URL : http://zakon.rada.gov.ua/laws/show/5067-17.

18. Силадій І. Нові тенденції в розвитку вітчизняної освіти. Вища освіти України. 2017. № 1. С. 56-64. 
19. Стратегія реформування освіти в Україні: Рекомендації освітньої політики. Київ : К.І.С., 2003. $296 \mathrm{c}$.

20. Сухарніков Ю. Методологічні засади перебудови і осучаснення вищої освіти України. Вища школа. 2015. № 11-12. С. 35-61.

\section{Referances:}

[1] Bebko, S. (2018). Perspektyvy rozvytku rynku osvitnikh posluh U krainy z urakhuvanniam kytaiskoho dosvidu. Vyshcha shkola. № 3. S. 62-70.

[2] Bolonskyi protses 2020 - Prostir yevropeiskoi vyshchoi osvity u novomu desiatyrichchi. Komiunike K onferentsii Y evropeiskykh ministriv, vidpovidalnykh za vyshchu osvitu. Loven / Luven-la-Nev, 2829 kvitnia 2009. URL: http://pedagogy. Inu.edu.ua/departments/ pedagogika/bolon/10.pdf.

[3] V sesvitnia deklaratsiia pro vyshchu osvitu dlia K hK hl stolittia: pidkhody i praktychni zakhody, 1998. URL: $\quad h$ ttp://euroeducation.org.ua/inshi-programni-dokumenty/1vsesvitnya-deklaraciya-pro-vyshchuosvitu-dlya-hhi-stolittya-pidhody-i.

[4] Hershunskyi B. S. Fylosofyia obrazovanyia dlia KhK hl veka (v poyskakh praktyko-oryentyrovannыkh obrazovatel nukh kontseptsyi). M oskva : Sovershenstvo, 1998. $432 \mathrm{~s}$.

[5] Holovenkin V. (2014). U niversytetska systema zabezpechennia yakosti. Vyshcha shkola. № 11-12. S. 1523.

[6] Darahan, T., Tymoshenko, N., Vlasiuk, O. A vtonomiia vyshchykh navchal nykh zakladiv: normatyvnopravovi akty, vstanovleni Zakonom U krainy "Pro vyshchu osvitu". Vyshcha shkola. 2017. № 7. S. 40-45.

[7] Dohovor o Evropeiskom Soiuze. Maastrykht, 7 fevralia 1992 h. URL: https://zakon.rada.gov.ua/ laws/show/994_029.

[8] Zinkovskyi, Y u. (2013). Imperatyv suchasnoi paradyhmy vyshchoi osvity. V yshcha shkola. № 9. S. 7-19.

[9] Ivlieva, L., Sidorina, Y e., K arbovska, S. Perspektyvy innovatsiinoho rozvytku osvity. Vyshcha shkola. 2013. № 10. S. 49-58.

[10] K limova, H. P. (2012). Innovatsiinyi rozvytok vyshchoi osvity U krainy: metodolohichnyi aspekt analizu. Aktualni pytannia innovatsi inoho rozvytku: V seukrainska naukovo-praktychna konferentsiia. № 3. S. 90105.

[11] K limova, H. P. (2016). Interpretatsiia poniattia "iakist vyshchoi osvity": sotsioloho-filosofska refleksiia. I urydychna akademiia Ukrainy imeni Yaroslava Mudroho : V isnyk Natsional noho universytetu. Seriia : Filosofiia. № 3. S. 34-44.

[12] K remen, V.H. (2015). Problemy yakosti ukrainskoi osvity $\vee$ konteksti suchasnykh tsyvilizatsiinykh zmin. U krainskyi pedahohichnyi zhurnal. № 1. S. 8-15.

[13] Kuklin, 0. V. K ontseptualni zasady innovatsiinoho rozvytku vyshchykh navchalnykh zakladiv. URL: http://www.economy.nayka.com.ua/?op =1\&z=1186.

[14] Lynovytska, 0. (2011). A kademichni svobody ta universytetska avtonomiia. Vyshcha osvita U krainy. № 3. S. 27-31.

[15] Pohrebniak, V., Dashkovska, O., Solodenko, A. 2018. Do problem stvorennia systemy zabezpechennia yakosti vyshchoi osvity u vitchyznianii vyshchii shkoli. Vyshcha shkola. № 7-8. S. 21-27.

[16] Pro vyshchu osvitu: Zakon Ukrainy vid 01.07.2014 № 1556-VII. URL: https://zakon.rada.gov.ua /laws/show/1556-18.

[17] Pro zainiatist naselennia: Zakon Ukrainy vid 05.07.2012 № 5067-VII. URL: http://zakon.rada.gov.ua /laws/show/5067-17.

[18] Syladii, I. (2017). Novi tendentsii v rozvytku vitchyznianoi osvity. Vyshcha osvity U krainy. № 1. S. 56-64.

[19] Stratehiia reformuvannia osvity v U kraini: Rekomendatsii osvitnoi polityky. K yiv : K .I.S., 2003. $296 \mathrm{s.}$

[20] Sukharnikov, Y u. (2015). M etodolohichni zasady perebudovy i osuchasnennia vyshchoi osvity U krainy. Vyshcha shkola. № 11-12. S. 35-61.

ОДАЙскИй С.И. Современные измерения и приоритеты развития высшего образования: сравнительный аспект.

Статья посвящена раскрытию современных идей, требований, приоритетов и позиций ученых в сравнительном аспекте относительно перспектив развития выстего образования Украинь и его интеграчии в европейское образовательное пространство, учитьвва автономию, академическую мобильность и академические свободы. Акиентируется внимание на вопросе изучения и внедрения в 
деятельность отечественных УВО европейского опыта высшего образования и достижений мировых университетов. Определяются пути обеспечения качества высшего образования и качества образовательной деятельности УВО в условиях общественных изменений.

Сделан сравнительный анализ идей, требований, приоритетов, научных позииий относительно перспектив и путей развития выстего образования в Украине в период реформационных образовательных преобразований; акиентирование тех аспектов, которые связаны с изучением и внедрением европейского опыта высшего образования на основе иелей и задач Болонского процесса и достижений университетов мирового уровня; освещены вопросы обеспечения системь качества высшего образования и качества образовательной деятельности УВО, внедрение автономии, академической мобильности и академических свобод; освещень изменения, происходящие в международном и национальном образовательном пространстве на современном этапе его развития, которые находят свое отражение в нормативно-правовых документах.

Акцентировано внимание на решении одной из важнейших задач развития выстего образования на современном этапе реформирования и модернизации образовательной отрасли, а именно: создание целостной системы обеспечения качества высшего образования Украины и успешной реализации ее составляющих в контексте современных образовательных изменений и воздействий, базируясь на стратегических иелях и задачах высшего образования. Научной и образовательной общественности важно выполнить дальновидную общественную миссию сохранить лучшие достижения украинской выстей иколь и предупредить потерю национальной идеи образования, содержание которой заключается в сохранении и приумножении национальных образовательных традиций.

Ключевые слова: высшее образование, учреждение высшего образования (УВО), автономия, академическая мобильность, академическая свобода, качество выстего образования, качество образовательной деятельности, Европейское пространство высшего образования (ЕПВО).

ODAYSKYS. I. Modern dimensions and priorities of higher education development: comparative aspect.

The article is devoted to the disclosure of modern ideas, requirements, priorities and positions of scientists in the comparative aspect regarding the prospects for the development of higher education in U kraine and its integration into the European educational space. The focus is on the study and implementation of E uropean higher education experience and the achievements of world universities in the activities of domestic IHES, taking into account autonomy, academic mobility and academic freedom. The ways of ensuring the quality of higher education and the quality of educational activities of IHEs in the conditions of social changes are outlined.

A comparative analysis of ideas, requirements, priorities, scientific positions regarding the prospects and development paths of higher education in Ukraine during the period of reformation educational transformations is made; emphasis on those aspects related to the study and implementation of the European experience of higher education based on the goals and objectives of the Bologna process and the achievements of world-class univer sities; the issues of ensuring the quality system of higher education and the quality of educational activities of SVR, the introduction of autonomy, academic mobility and academic freedom are highlighted; highlights the changes taking place in the international and national educational space at the present stage of its development, which are reflected in regulatory documents.

Attention is focused on solving one of the most important tasks of the development of higher education at the modern stage of reforming and modernizing the educational sector, namely: creating an integrated system for ensuring the quality of higher education in U kraine and the successful implementation of its components in the context of modern educational changes and influences, based on strategic goals and objectives higher education. It is important for the scientific and educational community to fulfill a far-sighted public mission - to preserve the best achievements of Ukrainian higher education and prevent the loss of the national idea of education, the content of which is to 
preserve and enhance national educational traditions.

Keywords: Higher Education, institution of higher education (IHE), autonomy, academic mobility, academic freedom, the quality of higher education, the quality of educational activities, European Higher Education Area (E HEA).

DOI: https://doi.org/10.31392/NZ-npu-142.2019.21

УДК 378.011.3-051:78:37.041

Пань Цяны

\section{СИТУАЦІЇ ВИБОРУ ЯК ЗАСІБ РОЗВИТКУ КРЕАТИВНОСТІ УЧНІВ ПІДЛІТКОВОГО ВІКУ У НАВЧАЛЬНО-МУЗИЧНІЙ ДІЯЛЬНОСТІ}

У статті розглянуто найважливіший педагогічний засіб розвитку креативності підлітків, ̈̈х активності, самостійності та індивідуальності, яким виступає спеціально спроектована ситуачія вибору в навчально-музичній діяльності, використання якої ставить школярів в умови, пов'язані з необхідністю віддати перевагу одному з варіантів, здійснити самостійний усвідомлений, адекватний $і$ значимий вибір. Автор статті пропонує й мотивує ситуації реального вибору; ситуації вибору навчальних завдань різного рівня; ситуачії вибору за певними критеріями; ситуації вибору навчальної мети, яка диференціюється за ступенем спрямованості; ситуації вибору за мотивацією досягнення мети. Простежено зв'язок між розвитком креативних якостей особистості учнів підліткового віку $i$ ситуацією вибору в навчально-музичній діяльності; виявлено потенщіал використання ситуації вибору як засобу розвитку креативності підлітків.

Розглянуто здатність до самостійної творчої діяльності і націленість на ї̈ результат, щзо сприяє підвищенню рівня креативності, представляє собою інтегровану якість особистості, в якій сфери психіки, властивості і якості учня пов'язані між собою.

До засобів, щуо активно впливають на розвиток креативності підлітків, належить ситуачія вибору в навчально-музичній діяльності, яка виникає в результаті зіткнення різних поглядів, використання завдань з багатьма даними або вибору з декількох способів найбільш рачіональних. Під ситуачією вибору розуміється сукупність обставин зовнішнього світу $i$ внутрішнього стану людини, на тлі якого актуалізується необхідність пошуку $і$ переваги однієї з прихованих або явних альтернатив.

Рімення завдань з неповними даними штовхає учнів на шлях самостійності добування знань, а постановка завдань із зайвими даними ставить їх перед проблемою вибору $і$ оцінки знань, активізуючи тим самим ӥх пошукову діяльність.

Ключові слова: ситуачії вибору, креативність, навчально-музична діяльність, освітній процес, вчитель музики, учні підліткового віку.

Загальноприйняте розуміння освіти, як засвоєння людиною досвіду минулого, набуває сьогодні протиріччя 3 його потребою у творчій самореалізації учнів. Здатність до творчості, що закладена в людині споконвічно, виражається в його прагненні до відкриття і створення нового в різних сферах життєдіяльності. Сучасній людині необхідно навчитися осмислено, грамотно і продуктивно діяти в нестандартних ситуаціях. У зв'язку з 